\title{
A tudásalapú társadalom pedagógiája és a számítógéppel segített tanulás
}

Ez a tanulmány az oktatási informatika fejlődésében a tömeges gépbeszerzéseket és a nagy arányú digitális taneszköz-fejlesztési programokat követő harmadik korszak néhány fontos irányzatát mutatja be, az oktatásra és a tanárképzésre koncentrálva. A bevezetőben a szerző nemzetközi iskolavizsgálatok alapján körvonalazza, hogyan modellezhető az informatikai eszközökkel gazdagított iskolai tanulási környezet jövőbeli fejlődése. Ezután a közoktatás egyik régóta megoldatlan problémája, a társadalmi esélyegyenlőtlenség kiküszöbölését célzó informatikai projekteket mutatja be, majd az oktatási eredményesség-vizsgálatokban keresi a választ arra az informatikai kultúra iskolai jövőjét meghatározó kérdésre, hogy valóban hatékonyabban, vagy „csak” élvezetesebben tanulnak-e a diákok informatikai környezetben.

A tanulmány néhány- az oktatási informatika fejlesztése terén jelentős eredményeket felmutató- európai ország jelenleg folyó nagy állami projektjeinek bemutatásával és a fejlődési irányok felvázolásával zárul.

\section{Szerzői információ:}

\section{Kárpáti Andrea}

Az Eötvös Loránd Tudományegyetem Természettudományi Karán az UNESCO segítségével létrehozott Információtechnológiai Oktatási Központ vezetôje, habilitált egyetemi docens, a neveléstudomány akadémiai doktora. Kutatási témái: az informatika hatása a tanulási képességekre és motivációra, a számítógéppel segített tanítás és tanulás új módszereinek kidolgozása és értékelése, a vizuális képességek fejlődése, a gyermekrajzok (plasztikák, fotók, filmek, tárgyak) lélektani, szociológiai és pedagógiai vizsgálata. Tizenöt szakkönyv és 157 tanulmány szerzôje, az „Informatikai módszerek az oktatásban” könyvsorozat (Nemzeti tankönyvkiadó) foszerkesztôje. Az Európai Neveléstudományi Társaság (European Association for Reserach on Learning and Instruction) vezetôségi tagja, az EU és az OECD oktatási informatikai szakértôii csoportjainak tagja, három nemzetközi folyóirat szerkesztô bizottságában dolgozik. Jelenleg „Az esélyegyenlőség elosegítése információ- és kommunikációs technológiákkal” című OECD kutatási programnak a roma általános iskolás gyermekek tanulási képességeit fejlesztô magyar projektjét vezeti.

\section{Így hivatkozzon erre a cikkre:}

Kárpáti Andrea. „A tudásalapú társadalom pedagógiája és a számítógéppel segített tanulás”. Információs Társadalom III, 2. szám (2003): 34-51.

$=\quad$ https://dx.doi.org/10.22503/inftars.III.2003.2.2

A folyóiratban közölt müvek

a Creative Commons Nevezd meg! - Ne add el! - Így add tovább! 4.0 Nemzetközi Licenc feltételeinek megfelelöen használhatók. 


\section{A tudásalapú társadalom pedagógiája és a számítógéppel segített tanulás}

A címben jelzett két fogalom közé akár egyenlôségjelet is tehetnénk - ha a múlt század utolsó évtizedeiben, a számítógépek tömeges iskolai megjelenésekor hangoztatott jóslatok (pl. Pelgrum-Anderson 1999) beválnak. Az új tudásszerzési eszköz, amely hálózatra kapcsolva az Internet gyakorlatilag korlátlan tudásbázisához nyújt hozzáférést és a tanulók személyre szabott oktatását, nevelését és önálló tanulását egyaránt szolgálja, pontosan azokat a célokat teszi megvalósíthatóvá, amelyeket a kor vezetố paradigmája, a konstruktív pedagógia tưzött ki: az egyénített, rugalmas, autentikus tartalmakat közvetítő, élet-közeli iskolai és magasabb szintû́ tanulmányokat.

Ebben a cikkben arra keressük a választ, hogy az új eszközrendszer fejlődésének első szakaszában - a Sulinet típusú hálózatok (Schoolnet, Schulweb, Réseaux scolaire stb.) tömeges kiépülésétôl, azaz a kilencvenes évektôl az Internet széleskörú elterjedésének koráig, a kétezres évek elejéig - mennyi valósult meg a reményekből, az oktatás informatizálása mennyivel járult hozzá a korszerû pedagógia kifejlődéséhez.

\section{A számítógépes kultúra és az iskolai élet}

Az ezredfordulón három - iskolai esettanulmányokra épülő - nagy nemzetközi vizsgálatot végeztek annak felderítésére, hogy a számítógépek tömeges megjelenésével hogyan változott az iskola mindennapi élete. Az International Educational Assessment (IEA) nemzetközi értékelő központ SITES2 elnevezésű kutatási programjának keretében 83 országban vizsgáltak reprezentatív mintákat kérdőívek és interjúk segítségével, valamint a tantervek, tanmenetek és oktatáspolitikai dokumentumok elemzésével (Kozma 2003). Az OECD „Információs és kommunikációs technológiák és az oktatás minősége” („ICT and the Quality of Learning”) című kutatási programja során 23 ország mintaszerû számítógép-felhasználó iskoláinak értékelése történt meg strukturált kérdőívekkel, interjúkkal és óralátogatásokkal, valamint a tanárok és a tanulók digitális múveinek elemzésével. (Venezky-Davis 2002; Venezky-Kárpáti, megjelenés alatt). Az EMILE mozaikszóval jelölt projektet az oktatási informatika európai hatását felmérô párizsi kutatóintézet vezette. Ennek keretében öt európai ország - az Egyesült Királyság, Görögország, Magyarország, Norvégia és Olaszország átlagosan felszerelt, de az információs és kommunikációs technológiákhoz (IKT) kapcsolódó kultúra iránt érdeklődő pedagógusokkal ellátott iskoláiban végeztek részvevő megfigyeléseket, a kulturális antropológia eszköztárát is alkalmazva (EMILE 2002). A részben eltérő módszereket alkalmazó három kutatás számos hasonló megállapításra jutott, amelyek alapján képet alkothatunk arról, hogy az IKT eszköztára hogyan terjedt el és mire használatos ma a közoktatásban. 
A számítógépesítés adataiból - melyeket az $O E C D$ például ma is egy-egy ország oktatási informatikai kultúrájának megítélésére használ - kiderül, hogy a 2000. évre egyértelműen kialakult a hozzáférési szakadék. Ez a megfogalmazás nem véletlen - szerintem nem beszélhetünk digitális szakadékról, amely az IKT kultúrában részesedőket választja el az abból kizártaktól, hanem „csak” arról van szó, hogy evvel a kultúrával egyesek könnyen ismerkedhetnek meg, míg mások osztozkodni, várakozni kényszerülnek. Amíg az Egyesült Államokban a 2002. évi adatok szerint a lakosságnak több mint 62\%-a, az Európai Unió országaiban pedig 45-55\%-a rendelkezik számítógéppel, Magyarországon ez az arány 10\%. Az európai uniós országokban 9-12 diákra jut egy számítógép az iskolában, nálunk 30 tanuló kényszerül osztozni egy gépen. Az Internet-ellátottsági ranglistát 2002-ben Izland vezette, ahol a lakosság 60\%-a rendszeresen használta a világhálót, az EU-átlag 45-50\% körül mozgott, ugyanakkoragyarországon $14 \%$ volt a használati arány. Valamennyi ország - a legjobban ellátottak is folyamatosan és nagy összegekkel fejleszti iskolai számítógép-parkját. A 2003 nyarán beindult Sulinet Express elnevezésû́ adókedvezményes lakossági gépvásárlási program - melynek keretében tanárok és diákok is kedvezményesen juthatnak az eszközökhöz - az alacsony szintű hazai gépellátottságon próbál segíteni. Egyfajta magyar modellnek számít, melyet érdeklődéssel figyelnek világszerte, $s$ ha beválik, bizonyosan követôkre talál.

Az állam gépet ad, vagy segít géphez jutni, de a fenntartást a felhasználóra bízza. Felújítási-szervizelési normatíva a három említett vizsgálatban összegzett több mint 600 esettanulmány egyikében sem szerepelt. Az informatikai kultúra sorsa az iskolákban tehát elsôsorban nem az ellátottságtól, hanem az iskolavezetés leleményességétôl függ. Ahol sikerül megtalálni a forrásokat a javításra, bôvítésre és fôleg a rendszergazda alkalmazására, ott a tanárok biztos technikai háttérrel, s így nagyobb kedvvel vágnak bele az informatikai megoldások alkalmazásába az oktatásban. Az alábbiakban összegezzük, mi jellemzi az IKT-kultúra elterjesztésében élen járó iskolákat:

- Az iskola vezetése egyértelmüen elkötelezett a számítógéppel segített tanulás mellett, ennek használatára ösztönzi a tantestületet, a sikeres alkalmazásokért jutalmazza a pedagógusokat, lehetőséget teremt a képzésre, illetve a továbbképzésre és állandóan pályázik az eszközpark karbantartásáért, bővítéséért.

- Az iskolai környezetben a számítógépek több helyen - tantermekben, közösségi tereken, irodákban és a tanárok felkészülését szolgáló szertárakban, tanári szobákban - megtalálhatók, az informatikai és más szaktárgyi PC-laboratóriumok ezt a közösségi ellátást egészítik ki šakirányú ellátással.

- A hivatalos belső kommunikáció - a hirdetmények, beadandó tanmenetek célba juttatása, az osztályzatok, órarendek és fogadóórák közzététele stb. - az iskola saját Intranet hálózatán zajlik

- Az iskolának legalább hetente aktualizált honlapja van, amely egyszerre szolgálja a külsố tájékoztatást (az „imázs-teremtést”), a tanulók szabadidejének szervezését és - versenyfeladatokkal, tantárgyi honlap-részekkel - az oktatást.

- A tanárok és a tanulók elektronikus levelezése rendszeres, a megoldandó iskolai problémákat megvitató fórumokra sok hozzászólás érkezik.

- Mind a pedagógusok, mind a diákok szívesen csatlakoznak hazai és nemzetközi virtuális közösségekhez, s az ott szerzett tudást jól felhasználják az iskolai munkában, föleg a nevelési kérdésekben. 
- A tanárok rendszeresen és szívesen képezik magukat az IKT és a hozzá kapcsolódó pedagógiai módszerek területén.

- A tanulók társ-alkotóként részt vesznek az iskola informatikai kultúrájának kialakításában.

Magáról a kultúráról a hozzáférési adatok tehát nem sokat mondanak, a pedagógiai eredmények nem feltétlenül azonosak a gazdasági rangsorral. A tanulók tudásában a PG- és Internet-ellátottság színvonala nem képeződik le közvetlenül, sốt, számos rosszul ellátott, de jól oktató nemzet (Magyarországon kívül ide tartoznak még a balti államok, Bulgária és Szlovákia) a nemzetközi tudásmérő vizsgálatok szerint sikeresen felkészíti tanulóit az informatikai kultúra múvelésére. Ez egyébként az egyik olyan terület, amelyen a magyar tanulók teljesítménye az utóbbi másfél évtizedben egyenletesen jó (Vári 2000). Az OEGD kutatás iskolai vizsgálatokat kísérô, öt országra kiterjedő tesztvizsgálatán Magyarország a tudásmérô tesztekben kiválóan, a képességtesztekben jól szerepelt (Kárpáti 2003). A nemzetközi informatikai diákolimpiák eredményei is jelzik, hogy az informatika nem olyan terület, ahol a jó teljesítmény okvetlenül kiváló infrastruktúrát feltételez. (A hivatásos programozók és fejlesztôk világában nyilvánvalóan egészen más a helyzet, de a jelen tanulmány az iskoláról szól.)

Nem lehet eléggé hangsúlyozni az iskolavezetés szerepét. Ha az iskola arculatát meghatározó igazgató és helyettesei maguk is aktív PC-használók és megszállott internetezők, a tantestület nagy valószínúséggel velük tart. Rogers (Rogers 1995) széles körủ nemzetközi hatáselemzésekkel kimutatta, hogy a pedagógiai innovációk elterjedését a legtöbb esetben egy-két elkötelezett és környezetében szakértőnek elfogadott személy kezdeményezi - ók az „innovátorok” (innovators), akiket a „korai alkalmazók” (early adapters) néhány fős csoportja követ. Ennek a két reformer-csapatnak az együttes létszáma még mindig csak a tantestület 15\%-ára tehetô, tehát létkérdés, meg tudják-e nyerni a „késôi alkalmazókat” (late adapters) - ők azok, akik „kivárnak”, amíg el nem dől, sikeres-e a reform, megéri-e az energiaráfordítást. Ha ez az 55\% is csatlakozik, már csak a „lemaradókat” (laggards) kell többé-kevésbé szelíd kényszerrel bevonni az átalakításba, vagy elkönyvelni veszteségként ezt a csoportot - a végeredményen az ő vonakodásuk már nem változtat. Fokozottan igaz az informatikára, hogy az oktatási reform kis lépésekböl álló, lassú, meggyózéses tanulás. Ha a vezetés áll az élre, gyorsabb a folyamat. A matróz hiába kiáltja: „Föld, föld!”, ha a kapitány másfelé irányítja a hajót.

\section{Számítógépekből épül híd a társadalmi szakadék felett?}

„Az esélyegyenlőség segítése informatikai eszközökkel” (Promoting Equity Through ICT) címú OECD projekt keretében Borsod megye 10 általános iskolájában zajló, roma fiatalok tanulási képességeit fejlesztô kísérletünk szervezésekor az egyik iskola igazgatója azt mondta, hogy bár ô nem tekinthetô az oktatási informatika elkötelezett hívének, mégis csatlakozik, mert szerinte minden esélyt meg kell ragadni, hogy egy tanulási probléma ne váljon életre szóló szociális hátránnyá. Ha kiderül, hogy az olvasni nem tudó kisdiák az oktató játék kedvéért betűre fogható, ha a tanuló tudásszintjéhez alkalmazkodó, tréfásan dicsérô és azonnal korrigáló gép kedvet csinál az elmélyült gyakorláshoz, akkor a szegény sorsú, kicsi falvakban is feltétlenül helye van. 
A nemzetközi tapasztalatok igazolják ezt a reményt. Figyelemre méltó, hogy a gyakorló tanárok és iskolavezetôk milyen gyakran említik - főként a tanulásban lemaradók esetében - az informatikai eszközök kedvező hatását. A SITES1 elnevezésû, számítógépes ismereteket és képességeket mérố vizsgálatban az informatika iskolai szerepérôl kérdezetteknek mintegy a fele fontosnak tartotta megjegyezni - bár ez a téma a kérdésekben nem szerepelt - hogy a gyengén tanuló, illetve az otthoni tanulásban akadályozott diákok számára (e két csoport között persze sok az átfedés) milyen sokat jelent a számítógép (Pelgrum 2003). India és Latin-Amerika országaiban ezért a gazdasági lehetőségeknek megfelelően szerény oktatási költségvetés igen jelentôs részét fordítják informatikai fejlesztésre.

Az Európai Gyógypedagógiai Fejlesztô Szolgálat (SNE - European Agency for Development in Special Needs Education, www.european-agency.org) nemrég jelentést készített, amelyben 17 európai ország gyógypedagógiai iskolahálózatának számítógéppel segített oktatási adatai szerepelnek, helyszíni vizsgálatok és szakértói jelentések alapján (SNE 2003). Az EU úgynevezett „salamancai nyilatkozatának” előírásai között szerepel az esélyteremtổ technológiák széles körû alkalmazásának bevezetése az iskolákban - az IKT ezek között az egyik leghatékonyabb. Az SNE jelentésébôl kiderül, hogy az infrastrukturális fejlesztés a fejlett országokban megtörtént, de igen kevés figyelem irányult a képzési tartalom kidolgozására. A speciális pedagógia igen sokféle olyan szoftvert igényel, amelyek az egészséges gyermekeknél nem használhatók, tehát ezeket nagy költséggel, kis piacra kell kidolgozni.

A standard irodai szoftverek és oktatási alkalmazások némelyike jól használható az esélyegyenlőség szempontjából különösen fontos speciális pedagógiai csoportokban. Használatukhoz három feltétel nélkülözhetetlen: a fogyatékkal élőket segítő interfészek (pl. a vakokat segítő szövegolvasók és hangos böngészők, a végtaghiányosoknak készült sajátos klaviatúrák), a speciális igényeket kielégítő szoftverek és a megfelelően felkészített pedagógusok. Az alapvetô szoftverek Európa-szerte rendelkezésre állnak, a probléma csak az, hogy használatukra nem képezik ki a gyógypedagógiai fốiskolák hallgatóit, és a végzetteknek sem kínálnak ezen a területen továbbképzố programot. Nagyon kevés módszertani segédanyag van, ami a különleges képzést igénylő tanulókkal foglalkozó pedagógusokat eligazítaná az IKT eszközök használatában. Ahol azonban használnak ilyeneket, ott a tapasztalatok kivétel nélkül kedvezốek. A hagyományos módszereket számos területen jól kiegészíti a számítógépes gyakoroltatás, sốt, a pszichomotoros képességek (például a szem-kéz koordináció), valamint az olvasási és számolási készségek bizonyos betegségekben szenvedôknél gépi környezetben hatékonyabban fejleszthetôk, mint hagyományos módon (Soriano et al. 2003).

\section{A számítógép mint trójai faló - úi oktatási módszerek informatikai környezetben}

Egy korábbi írásomban a számítógépet olyan trójai falónak neveztem, amely új oktatási módszereket csempész a tradicionális pedagógia bástyái mögé (Kárpáti 2000). Ma - alig fél évtizeddel a jelentős nemzeti számítógépesítési programok után - talán még korai megállapítani, hogy a falóból elóbújó harcosok sajnos kudarcot val- 
lottak: nem tudták áttörni, de még megkarcolni is alig tudták a hagyomány falait. Reményeink szerint a küzdôk még nem adták fel, az oktatási informatika még nem merítette ki erőforrásait, ső́t - a gépesítés és a hálózati kapcsolódások után - a harmadik fejlesztési korszak meghozza az áhított digitális tudásbázis kialakulását (a Sulinet új programja ezt ígéri), és a konstruktív pedagógia az informatika révén nyer majd teret napjaink iskolájában.

A fentebb említett esettanulmányok szerint az informatikai eszközök elterjedése a számítógépes laboratóriumokból indult, az innen leselejtezett gépeket használták először adminisztrációra, könyvtári nyilvántartásra. Míg a nyolcvanas években a programozást, a kilencvenes évektôl - a multimédiás gépek és a korszerú (vagyis az „elektronikus könyvnél” többet tudó, hangos-mozgóképes) CD-ROM-ok megjelenésétől - kezdve a tantárgyakhoz kötött felhasználói ismereteket oktatták elsősorban. Az IKT beépült a tantervekbe - Szingapúrban, Finnországban és Kanadában tananyagcsökkentés után, másutt a meglévő ismerethalmaz tetejére - de vajon az oktatók módszertani repertoárjába is beépült-e ez a világ? Vajon hajlandók és képesek-e a vizsgált iskolák pedagógusai átvenni a sokszor hangoztatott mentori feladatokat, s a „bölcs a színpadon” (,the sage on the stage”) valóban teret adott-e a „vezetô az oldaladon” (, a guide on the side”) szerepmodellnek?

Már a tizenkilencedik és a huszadik század fordulójának klasszikus nevelési reform-mozgalmairól is elmondható, hogy a korszerû pedagógiai paradigma mindig tanuló-centrikus, cselekedtető és aktív, míg a hagyományos, meghaladni kívánt eszmerendszer tanár-központú, passzív szemlélődésre és befogadásra alapozott volt (Kárpáti 2001). A szemléltetés az IKT-világban is éppen olyan egyeduralkodó, mint a klasszikus tábla-kréta módszer hívei, vagy az írásvetítő-használók körében. Mindhárom vizsgálat szerint $70 \%$ felett van azoknak a tanároknak a száma, akik főként erre használják a gépet. Az EMILE kutatási programba bevont átlagos felszereltségú iskolákban dolgozó, de a számítógépes kultúra iránt érdeklődő pedagógusoknál második helyezett a szövegszerkesztés, ezt 48\%-uk végzi rendszeresen. Ehhez a tevékenységhez tanulói feladatlapok és szóróanyagok készítése is hozzátartozik, tehát interaktív módszerek háttere is lehet. Harmadik helyen az egyéni felkészülés szerepel, az Interneten elérhető források felkutatásával, de ezt már a tanároknak csak 23\%-a jelölte meg a heti rendszerességgel végzett tevékenységek között. Mindössze $11 \%$-uk használt CD-ROM taneszközöket, és 5\%-nál kisebb volt azoknak az aránya, akik a tanulóknak kiadott, internetes keresést igénylő feladatokkal, online vizsgáztatással, testre szabott gyakorló programokkal aknázzák ki az IKT-kultúrában rejlő lehetôségeket.

Ha ezeket az eredményeket összevetjük azzal az interjú-kérdésünkkel, hogy vajon ismerik-e a tanárok ezeket a módszereket, s ha igen, tudnának-e példákat mondani a szaktárgyukban jól használható programokra, átlagosan 10\%-kal nagyobb arányban kaptunk igenlő válaszokat. Ismerik, sőt, elismerik ezeket - de nem használják. Ennek az oka a sokat emlegetett időhiány mellett az anyagi megbecsülés és a technikai háttér hiánya. Az innovatív iskolákban, amelyeket Magyarországon az OECD kutatási program során vizsgáltunk, az iskolavezetốk éppen erre a két problémára találtak megoldást a részmunkaidős segéderôk alkalmazásával és a pályázatokon nyert pénzösszegek, számítógépek és utazási lehetôségek jutalmazási eszközként való felhasználásával. Az eredmény nem maradt el: ezekben az iskolákban több mint három- 
szor annyi pedagógus, a tantestületi létszám 34\%-a használja rendszeresen az oktatási informatika korszerú módszereit. Ez a kultúra tehát - ha esélyt kap - vonzó és eredményes.

Az $O E C D$ vizsgálat keretében megnéztük, vajon igaz-e az a feltevés, hogy $a$ z $I K T$ a pedagógiai innováció kiváló katalizátora, különösen akkor, ha az Internetre épüló oktatási módszereket is alkalmazzák, vagy csak olyan iskolai környezetben tud elterjedni a számítógépes kultúra, ahol amúgy is folyik pedagógiai innováció, s a tanárok és diákok nyitottak az új pedagógiai módszerek iránt. (Feltételeztük, hogy az utóbbi esetben a számítógép nem több mint a reform-folyamat egyik eszköze.)

A kérdés vizsgálatakor különbséget kellett tennünk a katalizátor-szerep és a segítő szerep között. Ebben a kontextusban akkor tekintettük kataliæátornak az IKT eszközöket, ha valamely új pedagógiai megoldásra ösztönöztek, és akkor neveztük óket segitő szerepünek, ha meggyorsították egy pedagógiai innováció megvalósítását, amely más eszközökkel, más szellemi környezetben már kialakult és beindult. Az OECDországoknak a vizsgálatba bevont iskolái szinte kivétel nélkül „kísérletezők” voltak, amelyeknek csak azért volt szükségük az informatikai kultúrára, hogy ezzel bővítsék tovább az amúgy is impozáns módszertani repertoárjukat. A mintában szereplő vidéki kistelepüléseken múködô japán, portugál és izraeli iskolák az Interneten keresztül megvalósítható kommunikáció jelentőségét emelték ki, ami addig is jó teljesítményú diákjaikat országos, késôbb nemzetközi tanuló közösségek részévé tette, s így még jobb munkára ösztönözte (Venezky-Davis 2002).

Miért döntöttek az egyes iskolákban az informatikai eszközök bevezetése mellett? A 94 közül legalább 15 esettanulmányban szereplő okokat abban foglalhatjuk össze, hogy az iskola további fejlesztése csak az oktatáspolitika által erôsen preferált IKT területén volt lehetséges, mert ez az a terület, ahová a legtöbb pénz áramlik, ilyen témával érdemes pályázni. A munka világa megköveteli a magas színvonalú informatikai képességeket - az IKT használatát illetốen ez az az állítás, amellyel a legtöbb tanár, diák és szülő egyetért. Fontos feladat továbbá a diákok felkészítése az önálló tudásszerzésre, az élethosszig tartó tanulásra. Az informatikai képességrendszer iskolai fejlesztést igényel, otthoni kísérletezéssel, játékkal, cseteléssel nem fejleszthetô magas szintre.

A diákok teljesítményének javitása meglepően ritkán, éppen 15 esetben szerepel ebból is látszik, hogy az élenjáró iskoláknak ezen a területen nincs szükségük a számítógépek segítségére, az új kultúra náluk nem gerjesztett innovációt. A magyar eredmények azonban nem ezt mutatják: számunkra éppenséggel az igazolódott be, hogy az IKT bevezetése önmagában is jelentôs módszertani fejlesztési lehetóségeket nyit meg, az infrastruktúra javítása komolyan hat a pedagógiai munka színvonalára. Mintánkban a pedagógiai innováció a hatból négy intézményben közvetlen kapcsolatban állt a számítógépesítéssel - ezt mi sem bizonyítja jobban, mint hogy ez a folyamat két esetben jelentôsen lelassult, amikor vezetőváltás következtében megváltozott a helyzet az iskolában, s többé nem kapott akkora hangsúlyt a számítógéppel segített oktatás (minderrốl bôvebben ld. Kárpáti 2003).

Aminek tanúi vagyunk, nem más mint a technika domesztikációja (Petraglia 1998). A konzervatív pedagógia könnyúszerrel kiválasztja az oktatási informatikai repertoárból azt, ami számára kedvező, és elhanyagolja azt, ami praxisa megváltoztatására kényszerítené. A táblai rajzot a PowerPoint kép váltja fel, de ettốl az oktatás még nem lesz informatizált. A gép a konzervatív pedagógus kezében is vitathatatlanul megszelídül, 
csak azt tudja, amit a gazdája akar, és nem mutat többet a világból, mint egy írásvetítô. A korszerú pedagógia híve szintén „háziasítja” a számítógépet - ő is arra használja, amire saját paradigmáján belül szükség van, tehát projekt-feladatokat ad ki, amelyeknek a megoldásához az Interneten lehet információt keresni, tantárgyi web-lapot szerkeszt, hogy tanulóival közvetlenül megoszthassa új ismereteit, e-mailben segíti az órán kérdezni nem merő diákokat. Számára is „háziállat” a gép, de nem megbéklyózni való, veszélyes fenevad, hanem betanított, nagy erejú segítőtárs.

\section{Játszva tanulni? - Az IKT hatása az oktatás színvonalára}

A számítógéppel segített oktatás motiváló hatása közismert, minden jelentôsebb kutatás kimutat ilyen eredményt (pl. Venezky-Davis 2002; Wood 2002.). Ennél lényegesen bonyolultabb kérdés, hogy vajon mit és mennyit tanul a diák, ha informatikai környezetbe kerül. Változik-e az elsajátítás ideje, módja, hosszabb ideig rögzüle a digitális tananyag, mint a papíron vagy szóban közvetített? Számos kérdésre még keresik a választ, egy azonban bizonyos: a hagyományos iskola zárt követelményrendszerében a nyitott, rugalmas digitális információforrás nehezen él meg. A közelmúltban két nemzetközi meta-elemzés jelent meg, amelyek az informatikai eszközökkel segített oktatási kísérletek eredményességét azonos mintán vizsgálták. Az egyik (Mioduser et al. 2000) 436 publikált kísérletet tekintett át, s arra a szomorú következtetésre jutott, hogy ezek nagy többségében az „egy lépést előre a technikában, kettôt hátra a pedagógiában” elv uralkodik. Az alkalmazások nem növelik az elsajátítás színvonalát, sốt, a tanulók gyakran kevesebbet tudnak, mint gép nélkül oktatott kortársaik. Salomon (Salamon 2003) szerint viszont e kutatás kiindulópontja volt hibás - nem azt kell vizsgálni, hogy az informatikai eszközökkel gazdagított tanulási környezetek és pedagógiai programok mennyire képesek megfelelni a tegnap követelményeinek, vagyis a tesztre orientált, adatokat és tényeket számon kérô konzervatív értékelési hagyománynak, hanem azt, hogyan teljesítik vállalt feladatukat: a gondolkodtatva tanítást. Ó is átvizsgálta a kérdéses kutatásokat és a mérési eredmények alapján megállapította, hogy a vizsgált tanulók a logikai képességek fejlődésében, az önálló tanulásra való felkészülésben, a kreatív problémamegoldásban, továbbá az információk keresése, szúrése és feldolgozása területén kiválónak bizonyultak.

A legtöbb országra kiterjedố nemzetközi matematikai tudás-mérés, a TIMMS 1995 eredményeinek elemzésekor Hans Pelgrum (Pelgrum 2003) - az iskolában mért és az életben releváns tudás kettôsségét kimutatva - érdekes eredményekre jutott. Megállapította, hogy a leginkább innovatív, a legtöbb személyre szabott gyakorló programot és interaktív számítógépes tananyagot alkalmazó pedagógusok diákjai rendre rosszabbul teljesítettek a tesztekben, mint hagyományos módszerek szerint tanuló társaik. Ennek az oka a pedagógiai értékelés nemzetközi szaktekintélyének számító Pelgrum szerint egyszerû: a tesztek a magolóknak kedveznek, hiszen ismereteket kérnek számon, nem pedig képességeket vizsgálnak. A tanárok igen nehéz döntésre kényszerülnek. Ha vállalják az életszerú projekt-feladatokkal túzdelt és a tanulói megoldásoknak tág teret adó matematika-oktatási módszert, ezzel egyúttal szinte garantálják, hogy diákjaik kevéssé lesznek sikeresek a közvélemény számára igen fontos teszteléses vizsgálatokon. A helyzetet tovább árnyalja, hogy ugyanebből a vizsgá- 
latból kiderült: a számítógépet gyakran használó tanárok diákjai lényegesen jobban szeretik a matematikát, mint a többiek. Különösen jelentős eredmény, hogy a tantárgy iránti érdeklődés azokat is jellemzi, akiknek rossz osztályzata van matematikából - ốk is szívesen foglalkoznak vele és remélik, hogy eredményeik javulni fognak. Az a tanár tehát, aki visszatér a hagyományos módszerekhez, hogy jobb teszteredményeket érjen el, felettesei elismerését talán elnyeri, de a diákjaiét szinte bizonyosan el fogja veszíteni.

Szerencsére vannak olyan lényeges területek, ahol nem kell ilyen nehéz döntéseket hozni, mert az IK'T eszközök haszna nyilvánvaló. Ha a PIRLS 2001 elnevezésû nemzetközi oktatási eredményesség-vizsgálat adatait a háttérváltozókat is figyelembe véve összevetjük az otthoni számítógéppel való rendelkezés és a gép előtt eltöltött idő mutatóival, kiderül, hogy aki több időt tölt a számítógép előtt, jobban érti a szöveget, amit olvas, jobban érvel, könnyebben észreveszi a logikai kapcsolatokat és képes elemezni ezeket (Mullis 2003). Természetesen egy adott időpontban felmért adat önmagában nem elég bizonyíték, csak a trendelemzés fogja egyértelmúen kimutatni, hogy a számítógép eloótt levelezéssel, web-lapok böngészésével töltött idônek ténylegesen van-e pozitív kapcsolata az olvasási és szövegértési teljesítmény javulásával.

\section{Fejlesztő kutatás, kutató fejlesztés \\ - az informatika és a pedagógia a (közel)iövő iskolájában}

Az oktatási informatika lehetőségeinek feltárása csak gyakorlati úton, akciókutatással (a részeredmények alapján alakított pedagógiai programmal), részvevó értékeléssel (a kutatásban résztvevốk önreflexióit is felhasználó, a gyakorlat közvetlen megfigyelésén alapuló hatásvizsgálattal), pedagógusok és kutatók szoros együttmúködésével történhet. A felmérésekre továbbra is szükség van egy-egy fejlesztési szakasz lezárásakor, de ezek nem helyettesíthetik a kutatással kisért innovációt.

2002-ben az Európai Iskolai Hálózat (European Schoolnet) „Az IKT sorsa az európai oktatásban" címmel publikált összefoglaló jelentést, amely 22 ország oktatási informatikai kutatásait, fejlesztési programjait és képzési eredményeit összegezte (Wood 2002). A jelentés négy lehetséges forgatókönyvet fogalmazott meg, amelyek szerint az oktatási informatika további sorsa prognosztizálható az új évezred első évtizedeire.

Az első forgatókönyv szerint az IK'T minden eddiginél hatásosabb eszközt nyújt az iskolarendszer centralizálásához. A hálózatba kötött, „sulinetes” számítógépek minden akcióját naplózzák, a hálózaton gyors ütemben áramlanak a központi direktívák, tananyagok és módszertani előírások. Az adminisztráció gépesítésével és egységesítésével gyorsabb és hatékonyabb lesz az adatbányászat, az iskolák élete átvilágíthatóvá, napról napra nyomon követhetôvé válik.

A második, optimistább szcenárió szerint as iskolák „tanuló sæervezetekké” válnak. A digitális tudásforrásokhoz való közvetlen hozzáférés lehetôvé teszi a folyamatos, olcsó továbbképzést, a CD-ROM taneszközök gyorsan megújíthatók és testre szabhatók, végre nem kell évtizedeken át változatlan tartalmú tankönyveket használni. A tanárcsoportok együttmúködését virtuális tananyagfejlesztő környezetek és hálózati könyvtárak segítik, az új eszközökkel a vezetés és az adminisztráció is egyszerúbbé, könnyebbé válik. 
A harmadik elképzelés szerint az iskolák falai kitágulnak és befogadják a település intézményeit és vállalkozásait. Az erőforrásokat közösen használják, s az oktatásban is együttműködnek. Ez a mi általános mûvelődési központjainkra emlékeztetô, de a teleház-mozgalom elemeit is hordozó utópia az élethosszig tartó tanulás gondolatát ötvözi az autentikus ismeretszerzés elvével. Gyerekek és szüleik együtt, egy helyen, néha hasonló tananyagot dolgoznak fel, mindenki a saját szintjén, együttmúködve másokkal vagy önállóan gyakorolva. Az intézmények életközeli feladatokat adnak a diákoknak, akik cserébe megosztják az ott dolgozókkal az iskola számítógépes és szellemi erôforrásait.

Míg az elsố három elképzelés egyre szélesebb ívet húzott, amikor az IKT pedagógiai jelentőségét vázolta fel, a negyedik túlzottan is realista. Eszerint $a$ \& IKT divatja elmúlik, akárcsak az eddigi módszertani divatok. Egy lesz a munkaeszközök közül, amit az oktatás pillanatnyi igényei szerint használ vagy mellốz és nem válik pedagógiai kultúra-teremtő erôvé.

Hogy melyik válik be az elképzelések közül, csak kísérleti úton prognosztizálható. Nem kérdőíves felmérésekre, hanem akciókutatásokra van szükség. Innovatív pedagógiai programok iskolai kipróbálásával kell megvizsgálni, használt-e vagy ártott az iskolának a saját web-oldalak révén biztosított publicitás. Vajon megfelelő-e a központi oktatási információs rendszerek biztonsága, a beérkezô sokmillió adat - megannyi iskolai portré - kezelése, és mennyire válik előírássá a hálózaton keresztül vagy oktatási szoftver-dobozban érkező javaslat? Formálódnak-e tanuló közösségek az együtt dolgozókból csak azért, mert ma egyszerúbben elérhetók a képzési alkalmak és gazdagabb az információ-kínálat? Élő kapcsolatba léphet-e egy település az iskolájával, melyet nehezen tart fenn, s ha az újítani akar, vajon gyanakodva figyel? Elképzelhetô-e, hogy ez a rugalmas és kimeríthetetlennek látszó technika az iskolatévé vagy az episzkóp sorsára jut, tisztes unalomba fullad vagy a nehezen kezelhetô monstrumok közé, raktárba kerül?

„Az értelmes iskolák a memória trenírozása helyett az elme nevelésével kell, hogy foglalkozzanak" (Perkins 1992). Az informatika és pedagógia találkozásának akkor van értelme, ha ezt a feladatot végrehajtja.

A legjobb gyakorlat példáival foglalkozik az Európai Unió Oktatási és Kulturális Igazgatóságának (EU DCE) „Multimédia, kultúra, oktatás és képzés” szekciója által indított és jelenleg is folyó (2002-től 2012-ig tartó) nemzetközi kutatási program, amelyben valamennyi jelenlegi és leendô tagország oktatási minisztériuma kutatócsoporttal képviselteti magát. A munka célja olyan - a jövendő tanterveit meghatározó oktatási célok (Future Objectives of Education) meghatározása, amelyek a jelen legjobb megvalósult gyakorlati példáira épülnek. Az „IKT az oktatásban” (ICT in Education) elnevezésû̉ munkacsoport elsố jelentésében több mint 200 mintaszerû oktatáspolitikai kezdeményezést gyüjtött össze (EU DCE 2003). Mintaszerúnek azokat a kezdeményezéseket ítélték, amelyek korszerű oktatási célokat valósítanak meg, innovatív IKT megoldások segítségével, országos szinten jelentôsnek mondható (tehát nemcsak egy-két iskolára vagy egyéb intézményre kiterjedő) hatókörrel. Terveket nem, csak már megvalósult, illetve folyamatban levő projekteket lehetett jelölni. Az EU szakértői által kidolgozott kérdőíven meg kellett jelölni, van-e kapcsolat az adott projekt és az IKT között. Az EU eddigi szakértői felmérései szerint az IKT oktatási alkalmazásának problematikus területei a következők: 
- az anyagi háttér folyamatos biztosítása, a fenntartható fejlődés;

- a tanuló-típusok sajátosságainak figyelembe vétele (különös tekintettel a tanulást újrakezdő felnőttekre, a kisebbségekhez tartozó diákokra és egyéb hátrányos helyzetú csoportokra);

- a digitális tananyag sajátosságainak figyelembevétele;

- a tanárképzés és továbbképzés megszervezése a projekt eredményeire építve.

Mindezek olyan problémák, amelyek az EU legfejlettebb országaiban is aktuálisak. Az alábbiakban ezek közül említek néhányat, hiszen jól jelzik, hogy az oktatási informatika milyen irányt vesz a harmadik évezredben azokban az európai országokban, amelyek ezen a területen élen járnak.

Auštriában (www.eFit-Austria.at) az oktatási informatikai stratégia és a hozzá kapcsolódó pályázatok, projektek összefoglaló neve eFit-Austria. Az informatikai fejlesztési programok az oktatás minden résztvevőjét - a közoktatás 1,2 millió tanulóját, az egyetemek 200 ezer diákját és az oktatási intézmények összesen mintegy 120 ezer tanárját - érintik. Teljes körú modernizációról van szó, amelynek célja az informatikai eszközök felhasználásának kiterjesztése valamennyi iskolatípusra és tantárgyra. A 21 millió euróval támogatott projekthez számos tananyag készült (www.bildung.at), amelyeket bármely osztrák iskola ingyen használhat. A tanárképzésben „Oktatási informatika" B.A. és M.A. képesítési fokozatokat vezetnek be, ami azt jelenti, hogy minden tanár - bármilyen szakos legyen is - fóiskolai vagy egyetemi szinten továbbképezheti magát ilyen irányban. A magán szektor és a közszféra partneri viszonyának elősegítésére az egyetemek és a szoftvercégek közös pályáztatásával (ennek a NagyBritanniában remekül bevált modellnek az alkalmazásával) fejlesztik a tanárképzési programokat. Az ECDL vizsgarendszer múködtetése mellett Java-Sun és Linux nemzetközi felhasználói vizsgára előkészítő tanfolyamokat is szerveznek. Az ország valamennyi állami forrásokból finanszírozott oktatási honlapját közös portálon keresztül kívánják elérhetôvé tenni (www.virtual-learning.at), amelyen keresztül a tartalom szûrése és értékelése központi szakértői csoport közremúködésével megoldható.

Az osztrák pedagógiai innovációs programok közül a legérdekesebb talán az IK'T használatában élenjáró, követendő modellnek tekintett iskolák egy-egy osztályának ellátása tanulói és tanári laptop számítógépekkel. Ez a 2000/2001 tanév óta alkalmazott, jelenleg (a 2003/2004 tanévben) már 150 iskolát érintő kísérlet lehetővé teszi, hogy a tanárok saját digitális tankönyveiket használják (amelyeket többféle, a kereskedelemben kapható, vagy saját készítésú információforrásból válogattak össze) és a diákok ezeket a tankönyvbe beleírt jegyzeteikkel, szintén digitális formában házi feladatként készített képgyưjteményeikkel, esszéikkel és kiselőadásaikkal személyessé tegyék. Az osztályokban eddig lezajlott két teljesítmény-értékelés (http://wbt.donauuni.ac.at/notebook) azt mutatja, hogy a tanulók fejlődése minden tantárgyi területen kiegyensúlyozottan emelkedő tendenciájú és lényegesen gyorsabb, mint hasonló képességú, hagyományos taneszközökkel dolgozó társaiké. A kísérlet párhuzamosan halad hasonló német, holland és svájci kezdeményezésekkel, amelyek jelentős hatást gyakoroltak a hordozható számítógépek technikai és szoftver-megoldásaira egyaránt. A pedagógiai gyakorlatból eredő ilyen innováció például a digitális palatáblának nevezett tablet $P C$ fejlesztése. Ennek a mindössze másfél kilogramm súlyú eszköznek a 180 fokkal elfordítható monitorja kiválóan alkalmas demonstrációs célokra, érintő-képer- 
nyője digitális ceruzával a hagyományos jegyzetblokkhoz hasonló könnyedséggel kezelhető. Az osztrák IK'T fejlesztési modell egyszerre támogatja a tanárképzést és a technikai innovációt. Legfő́bb célja az, hogy a pályakezdố pedagógusok - haladó oktatási informatikusként, magas színvonalú IKT ismeretekkel felvértezve - iskolájukban az új pedagógiai kultúra terjesztőivé váljanak.

Belgiumban az IK'T kultúra terjesztésének legfontosabb célja olyan segitő hálózat kialakítása, amely gyors és hatékony szakértôi támogatást nyújt az informatikai eszközöket alkalmazó iskoláknak (www.ond.viaanderen.be/ICT). Az egyetemek, fóiskolák és pedagógiai intézetek munkatársaiból szervezett országos hálózatot az oktatási minisztérium finanszírozza, a regionális csoportokba szervezett szakemberek minden iskola számára ingyenesen, folyamatosan rendelkezésre állnak. Az 1.860 .000 euróval támogatott, kétéves projekt azon a felismerésen alapul, hogy az iskolákban azért torpant meg az IK'T eszközök alkalmazása, mert a tanárok napi munkájuk mellett képtelenek megbirkózni a folyamatosan megújuló szoftverkínálat megismerésének és célszerű alkalmazásának feladatával. Ezenfelül számos olyan technikai probléma is adódik, amit a helyi számítógép-karbantartók nem képesek megoldani. A szakértốk tehát egyszerre nyújtanak hagyományos helpdesk szolgáltatást és gyors, célirányos pedagógiai továbbképzést.

Az így támogatott tanárok legfontosabb igénye a háromféle nemzetiségi alaptantervhez illeszkedő - flamand, francia, illetve vallon nyelvú - oktatási anyagokhoz való hozzáférés. Ezt szolgálja az Anywize projekt, amely 2003-ban indult és meghatározatlan ideig tart (www.anywize.be). A projekt középpontjában egy oktatási szerver felállítása és múködtetése áll, amelynek célja kipróbált elektronikus tananyagok eljuttatása a felhasználókhoz: a szaktanárokhoz és a tanulmányaikhoz kiegészítő anyagot keresố diákokhoz. A fejlesztési program, amely az elemi, a középfokú és a felsôoktatás számára szerényen mindössze évente 15 tananyag kidolgozására vállalkozik, szerencsés módon ennél lényegesen több, évi 40 tananyagot készít a legkevésbé ellátott speciális képzésnek, a szellemi fogyatékkal élók oktatásának segítésére. A saját fejlesztésû́ anyagokon kívül közreadják a tanárok által készített és publikációra megvásárolt taneszközöket és prezentációkat is. A portálnak on-line értékelő fóruma és help-deskje van (ez utóbbi telefonon is hívható), mindkettő a tanári vélemények összegyújtésére szolgál. Ha az iskola úgy dönt, hogy a hagyományos, ,jelen idejû” képzésen felül távoktatási formákat is felhasznál, hogy a tananyagok a diákok számára mentorálással együtt - otthon is hozzáférhetôk legyenek, erre is van mód: a portálról ingyenes távoktatási környezet érhetô el. A szolgáltatást csak azok az iskolák tudják igénybe venni, ahol szélessávú Internet-hozzáférés és multimédia prezentációs eszközök vannak, tehát le tudják tölteni, majd a tanórákon fel is tudják használni a tananyagokat. A beszámolók szerint a belga iskoláknak mintegy a fele ilyen, a többieknek pedig ösztönzést jelent, hogy a technikai fejlesztés után rögtön taníthatnak is a digitális eszközökkel, hiszen ezeket nem kell kockázatosan, reklámanyagok alapján kiválasztani és megvásárolni, hanem ingyenesen rendelkezésre állnak egy „államilag garantált", ellenőrzött minőségű portál kínálatában. Holland pedagógusok is igénybe vehetik a portált, hiszen a tananyagok egy része az ô nyelvükön készül. (Ez a belga fejlesztôk számára is igen elônyös, hiszen cserébe sok tananyagot kapnak szabad felhasználásra az IKT alkalmazásában élenjáró ország oktatóitól.) A belga modell tehát a gyakorló tanárokat segíti, a fejlesztési programokat széles körü segítő szolgáltatásokba 
ágyazza, s a hangsúlyt nem új és még újabb oktatási innovációk kidolgozására, hanem a meglévôk elterjesztésére helyezi.

Dániában az oktatási informatika fejlesztésének középpontjában ma nem a hagyományos képzés, hanem egy dán sajátosság: a népfőiskolai hálózat (Folkeskole) számítógépesítése áll. 2000-ben a dán parlament 45 millió eurós fejlesztési tervet fogadott el, amelyben a felnőtt-képző intézmények ellátása e-learning útján elsajátítható tananyagokkal és a tanárok felkészítése szerepelt (www.itmf.dk). A 6-12 hónapos, tehát alapos és hosszú tanárképzési programok elsố sorozatának végén pályázati forrásokat nyitottak meg, melynek eredményeként több mint 100 oktatási informatikai innovációs program indult be a korábban ezen a területen nem túl gyors fejlődést mutató országban (www.school-ict.org). A sikeres iskolák munkájának megismerése érdekében odalátogató csoportokat szerveznek, amelyekben a módszert átvenni kész intézmények oktatói, pedagógiai kutatók és informatikusok vesznek részt. A látogatók a helyszíni tapasztalatok alapján olyan értékelő jelentést készítenek, amelynek legfóbb célja az új program elterjesztésének segítése, buzdítás a jó példa követésére. A dán modellt, amely tehát tanár-továbbképzéssel készít fel az innovációra (s erre pályázati források bőséges rendelkezésre bocsátásával azonnal lehetőséget is ad), majd helyszíni tapasztalatszerzésen alapuló partneri értékeléssel gondoskodik az államilag támogatott jó gyakorlat elterjedésérôl, Norvégia is átvette és sikerrel alkalmazza.

A $S k o D a$ nevű iskolai adatbázis-kezelő rendszeren keresztül valamennyi dán iskola oktatási anyagai hozzáférhetốk, amennyiben ezeket állami forrásokból fejlesztették ki és megosztásuknak nincs jogi akadálya. Amint már az eddigiekbôl is látható, minden országban vannak nemzeti szoftver-megosstó (clearinghouse) programok, s ezeknek a múködése a módszertani fejlődés alapfeltételei közé tartozik.

Észtország 1998-tól, az országos oktatási informatikai hálózatok elsố megjelenésétôl kezdve élenjárónak számít ebben a kultúrában, hiszen nemzeti jövedelméhez képest igen jelentôs összegeket költ az iskolák számítógépes ellátására (www.tygrihype.ee/eng). Évente több pályázatot írnak ki szoftverfejlesztésre, ugyanis a körülbelül 1,7 milliós lakosság nem jelent számottevő piacot a nemzetközi cégek számára, az iskolák észt nyelven csak a hazai fejlesztésú tananyagokra számíthatnak. Az állam teljes egészében fedezi a szoftverfejlesztés költségeit, ha pedig egy iskola külföldi tananyagot akar vásárolni, a vételár $50 \%$-ára pályázhat. A program részét képezi - akárcsak más országokban - iskolai laboratóriumok felállítása, Internet szolgáltatás és regionális szervizeken keresztül nyújtott technikai segítség. A „Tigrisugrás” címú ambiciózus projekt a korábban említett országokhoz hasonlóan szintén a tanárképzést és a tanár-továbbképzést tartja a legjelentősebb megvalósítandó feladatnak (www.koolielu.ee). A képzési programok központja a Tallini Egyetem tanárképzô kara, ahol „Multimédia oktatási rendszerek” címmel kétéves, M.A. szintű képesítést nyújtó pedagógusképző program fut, távoktatásos és hagyományos módszerek ötvözésével. A programban az oktatásmenedzsment szoftver-támogatása éppúgy szerepel, mint a szoftverfejlesztés alapismeretei és a „digitális didaktika” (http://www.cs.tpu.ee/magister/kavad/informatics_english.htm).

Finnország az oktatási informatika egyik legfontosabb európai szereplôje: minden paramétert tekintve - az egy számítógépre jutó diákok arányától a digitális tananyagfejlesztésre költött összegekig - az élen áll (www.edu.fi). Az ország közoktatási intézményeinek számítógépes alap-felszerelése és Internetre csatlakoztatása 2002 
végén befejeződött, a jelenlegi második fejlesztési szakaszban az új oktatási formák kidolgozásáé a főszerep. A közoktatás legfontosabb innovációs projektjeirôl részletes angol nyelvû honlapok tudósítanak. Néhány példa:

- A Netlibris az irodalomoktatást segíti digitális tananyagokkal (www.netlibris.net/english). Az Interneten rendszeresen megjelenô felhívásokra válaszoló diákokból virtuális szemináriumi csoportokat alkotnak, melyek moderált vitafórumon cserélik ki véleményüket egy-egy irodalmi műről. A diákok a mú olvasása közben naplót vezetnek, tehát saját gondolataik és a vitafórumon olvasottak együtt formálják ítéletüket, és a kortársakkal folytatott elektronikus csevegés közben (ami ott is a tinédzserek kedvenc időtöltése) szinte észrevétlenül gazdagítják irodalmi műveltségüket.

- A „Kézmứvesség virtuális osztályterme” elnevezésû́ honlap (www.tkukoulu.fi/handmade/eng) a hagyományos finn népi kézmúvességtől a világhírű kortárs formatervezésig mutatja be és feladatokkal tanítja a környezetkultúrát.

- A „Középfok utáni képzés” nevû́ honlap segítségével (www.oph.fi/etalukio/english) azokat a fiatalokat oktatják e-learning módszerekkel különféle szakmákra és az egyetemi, főiskolai felvételi vizsgákon szereplő tantárgyakra, akik nem kerültek be a felsôoktatásba.

A legérdekesebb projekt azonban a felsőoktatás modernizálását szolgálja: ez a Finn Virtuális Iskola (www.virtuaaliamk.fi), melynek honlapja angol nyelven is rendelkezésre áll (www.minedu.fi/julkaisut/information/english). A projekt lényege a finn egyetemek és főiskolák erőforrásainak koncentrálása. Ezek az intézmények kurzusaik egy részét felajánlották a többiek diákjai számára, akik távoktatással végezhetik el a kurzusokat, melyeket hagyományos helyszíni szóbeli vagy zárthelyi tesztvizsga zár le. A digitális könyvtárakat és képarchívumokat, virtuális laboratóriumokat és más költséges forrásokat szintén közösen használják, sôt, egyetemközi projekteket is szerveznek a hallgatók részére, hogy azok nemcsak a tananyagot, hanem az egyetemeket jellemzố sajátos munkakultúrát is megosszák egymással. Az együttmúködést az állam igen jelentős összegekkel és a korábban finanszírozott tananyagok terjesztôi jogainak rendelkezésre bocsátásával támogatja. A közösen felépített, robusztus távoktatási környezetben a legfontosabb módszer a telekonferencia, amit rutinszerủen használnak előadások közvetítésére és több egyetem diákjainak egyes szemináriumokon való közös részvételére egyaránt. A levelezôfórumok tematikusan szervezett, visszakereshető közleményei képlékeny és az aktuális diákcsoport igényeit jól követô tananyagként múködnek. A programban résztvevő diákok folyamatosan követik az elektronikus hirdetôtáblákat, amelyek az egyes intézmények aktuális kínálatáról és a program keretében szervezett speciális eseményekrôl tudósítanak. (Egy-egy vendégelőadó így - bárhová is hívták - hallható és látható az ország valamennyi egyetemén.) A hírcsoportok kiválóan alkalmasak az ország egyetemein $M A$ és $P h D$ képesítésüket hasonló témában megszerző hallgatók tájékoztatására tudományterületük fontos eseményeirốl. (Így áthidalható a tudományos pályát alapvetôen befolyásoló információs szakadék a jó kapcsolatrendszerrel rendelkező nagy egyetemek és a szegényebb intézmények tudósjelöltjei között.) Könnyen belátható, milyen elônyökkel jár egy ilyen, falak nélküli össztársadalmi intézmény, de az is nyilvánvaló, mennyire nehéz megszervezni a több tucat településen élő több tízezer diák szabad vándorlását 
a különféle kurzusok és eszközök között. A Finn Virtuális Iskola oktatásszervezôi ezért az elektronikus kapcsolattartás mellett havonta hosszabb személyes megbeszéléseken tisztázzák a problémákat, s egyfajta virtuális tantestületet alkotva gondozzák a gigantikus új felsôoktatási képződmény mindennapi életét.

A Német Szövetségi Köztársaság oktatási rendszerének az a sajátossága, hogy az egész országot átfogó, nagy nemzeti programok az egyes szövetségi tartományok saját IKT politikája mellett, annak kiegészítéseként jelennek meg. Először ezek közül említem meg a legjelentősebbeket. Itt is van digitális tananyag-tár, amelyet a LehrerOnline program keretében fejlesztenek és töltenek meg tartalommal (www.lehreronline.de). Ez a mi Sulinetünkhöz hasonló, információs és szolgáltató portál valamennyi közoktatási intézménytípus oktatóinak nyújt aktuális oktatási informatikai híreket és ingyenes taneszközöket. A 600 ezer német pedagógus havonta 300 ezer alkalommal keresi fel a szervert, amely virtuális osztálytermi szolgáltatásai révén arra is alkalmas, hogy egyszerû web-kamerás közvetítéssel egy tanórára vagy projekt-megbeszélésre „összehozza” a nagy kiterjedésú ország iskoláinak diákjait. A portál munkatársai maguk is fejlesztenek tananyagokat és közös oktatási akciókat indítanak. Az oldal tetején elhelyezett szöveges keresôben Exil-Club néven fellelhetô program jelentôs európai együttmúködés keretében ma is folyik, témája a menekültek helyzete. A tananyag nemzetközi fejlesztő csapata egymás mellé helyezte a huszadik század nagy migrációinak sokszor fájdalmas, nemzeti érzékenységeket érintő folyamatait és ezzel őszinte számvetésre ösztönözte a programba bekapcsolódó tanárokat és diákokat egyaránt. A német Sulinet iroda neve „Iskolák a hálón” - ennek honlapja (www.schulen-ansnetz.de) harcias szellemében különbözik a világ más iskolai oldalaitól. Jelenleg (2003 szeptemberében) a gyermek-pornográfia elleni fellépés módszereiről olvashatunk, kampány folyik a szoftver-kalózok ellen, az „Aktuálpolitika” címú állandó (!) rovatukban pedig Irak és az ENSZ viszonya a téma. Akárcsak az esztétikai nevelésben, ahol Németország a mi nemzeti alaptantervünkben is szereplő vizuális kommunikáció mûveltségterületén öntudatos médiafogyasztóvá nevelési programjaival mutatott példát mindenkinek a világon, az IK'T oktatásában is dominál a társadalmi tudatosság, az állampolgári nevelés céljainak integrálása az informatikai kultúrával.

A német közvélemény mindig is sokat foglalkozott a nők helyzetével, s ehhez a kérdéskörhöz kapcsolták a lányok informatikai nevelésének sajátosságait és a cyberkultúra nôi oldalainak megismerését. A LizzyNet (www.lizzynet.de) elnevezésű kamaszlány-portál olvasótábora és legtöbb szerzôje egyaránt a 14-18 éves korosztályhoz tartozik. A honlapot a szövetségi oktatási és kulturális minisztérium támogatja és évente hatásvizsgálattal követi. Ennek eredményei igazolják, hogy az oldalon rendszeresen böngészôk számítástechnikai ismeretei és készségei fejlődnek. Ezen a honlapon érhetố el a LizzyPress címú újság, amely várja az olvasók cikkeit és képeit, ugyanitt kísérletek végezhetôk a kutató nők által fejlesztett LizzyLearningLab nevű virtuális laboratóriumban, s izgalmas történetekkel körített információk jelennek meg olyan természettudományos területekrôl, amelyeken igen kevés nô dolgozik, pedig sajátos habitusukra szükség lenne. Természetesen van csevegó fórum és a tinédzser magazinok életmód-oldalai sem hiányoznak. A virtuális tanfolyamokat tízezrek látogatják, az ország minden részében szervezett programokra ezrével sereglenek a lányok. A honlap kiválóan egyensúlyozik a hétköznapi és az „ünnepi” kultúra mezsgyéjén, egyszerre népszerüsít és szórakoztat. 
Amint az itt vázlatosan bemutatott innovációs programok mutatják, a tudásalapú társadalom polgárainak oktatásában Európa-szerte egyre több informatikai eszközt alkalmaznak. Az IKT változatlanul a legjelentôsebb innovációs tétel az oktatási büdzsékben, hatásával és hatékonyságával a legjelentôsebb kutatóhelyek foglalkoznak. Szerepe megkerülhetetlen, s az is nyilvánvaló, hogy elterjesztésének legfontosabb feltétele a jól képzett s az ügynek lélekben is megnyert pedagógus. Ezért irányul jelentős kutatás és fejlesztés világszerte a tanárképzésre és a továbbképzésre, ezért igyekeznek a felsőoktatásban is megjeleníteni azokat a módszereket, amelyeket az iskolákban kívánatosnak tartanak. A számítógép okozta pedagógiai földcsuszamlásnak ebben a harmadik szakaszában az eszközök beszerzése és az oktatási szoftverek elsố generációjának fejlesztése után immár az ember került a középpontba - a pedagógus, akirôl a szakfolyóiratokban is patetikus költôiséggel írnak: a mentor, a vezetô, a mester. Ezt a számunkat neki ajánljuk.

\section{IRODALOM}

Argyris, C. - Schon, A. D. (1996): Organizational learning II. USA: Addison Wesley

Becker, H. (1994): Analysis and trends of school use of new information technologies. U.S. Congress Office of Technology Assessment, Washington, D.C.: U.S. Govt. Printing Office

Benavot, A. (2001): Institutional approach to the study of education. In: Allantine, H. J. Spade, Z. J. (eds.), School \&̊ Society (pp. 409-416). USA: Wadsworth

Cuban (1986): Teachers and machines: The classroom of technology since 1920. New York: Teachers College Press

DiMaggio, P. - Powell, W. (1991): The iron cage revisited: institutional isomorphism and collective rationality in organizational fields. In: P. J. DiMaggio - W. W. Powell (eds.), The new institutionalism in organizational analysis (pp. 63-82), Chicago: University of Chicago Press

di Sessa, A. (2000): Changing minds - computers, learning and literacy. Cambridge, MA: MIT Press

EMILE - Educational Multimedia in Europe, www.emile.eun.org

Fullan, M. (2001): The new meaning of educational change (3rd ed., chap. 7, pp. 115-136). New-York: Teachers College, Columbia University.

European Union, Directorate of Education and Culture (2003): Group C Draft Report. Bruxelles: European Union. (Az angol nyelvű szöveg decembertől az Oktatási Minisztérium honlapjának az Európai Unióval foglalkozó részén olvasható lesz.)

Hanson, M. (2001): Institutional theory and educational change. Educational Administration Quarterly, 37(5), 637-661.

Hargreaves, A. (2002): Sustainability of educational change: The role of social geographies. Journal of Educational Change, 3(3-4): 189-214. 
Kárpáti Andrea (1997): A befogadásra és az aktivitásra épülô nevelési folyamatkoncepciók jellemzői. In: Bábosik István (szerk.): A modern nevelés elmélete, III/3. rész Budapest: Telosz Kiadó, 1997 164-184.

Kárpáti Andrea (2000): ICT in Hungarian Education: Who/What is Inside the Trojan Horse of Education? International Journal of Educational Policy, Research and Practice, Vol. 1, No. 3, 2000, pp. 287-307

Kárpáti Andrea (2002): Az OECD „IKT és az oktatás minősége” c. kutatásának zárójelentése. Oktatási Minisztérium, kézirat

Kárpáti Andrea (2003): Az informatika hatása az iskola szervezetére, kommunikációs és oktatási-nevelési kultúrájára. Új Pedagógiai Szemle, 2003/8

Kozma, R. (ed.) (2003): The SITES2 Study. Hamburg: IEA

Lamon, M., Secules, T., Petrosino, T., Hackett, R., Bransford, J. D. \& Goldman, S. R. (in press): Schools for thought: Overview of the international project and lessons learned from one of the sites. In: L. Schauble - R. Glaser (eds.), The contributions of instructional innovation to understanding learning. Hillsdale, N.J.: Lawrence Erlbaum Associates

Mioduser, D. - Nachmias, R. (2002): The WWW in education: An overview. In: H. Adelsberger, B. Collis - J. Pawlowski (eds.), Handbook on Information Technologies for Education and Training (pp. 23-43). Berlin: Springer-Verlag

Mioduser, D., Nachmias, R., Lahav, O., \& Oren, A. (2000): . Journal of Research on Computing in Education, 33(1): 55-76.

Mioduser, D., Nachmias, R., Tubin, D., \& Forkosh-Baruch, A. (2003): Analysis Schema for the Study of Domains and Levels of Pedagogical Innovation in Schools Using ICT. Education and information technologies, 8(1): 23-36.

Mullis, I. V. S., Martin, M. O., Gonzalez, E. J., \& Kennedy, A. M. (2003): PIRLS 2001 International Report. IEA's Study of Reading Literacy Achievement in Primary Schools in 35 Countries. Chestnut Hill, MA: Boston College

Nachmias, R., Mioduser, D., Forkosh-Baruch, A., \& Tubin, D. (2003): ICT Policies and Practices in Education - ISRAEL. In: T. Plomp, R. Anderson, N. Law \& A. Quale (eds.), Cross-National ICT Policies and Practices in Education. Information Age Publishers

Nachmias, R., Mioduser, D., Oren, A., \& Ram, J. (2000): Web-supported Emergent Collaboration in Higher Education Courses. Educational Technology \& Society, 3(3): 94-104.

Ogawa, T. R., Crowson, L. R., \& Goldring, B. E. (1999): The Dilemmas of School Organization. In: J. Murphy, \& K. A. Louis, (eds.), Handbook of research on Educational Administration (2nd ed., pp. 277-295). San Francisco: Jossey-Bass

Olson, D. (1994): The World on Paper: The Conceptual and Cognitive Implications of Writing and Reading. Cambridge: Cambridge University Press

Oren, A., Mioduser, D., \& Nachmias, R. (2002): The Development of Social Climate in Virtual Learning Discussion Groups. International Review of Research in Open and Distance Learning, 3(1): 1-19.

Pelgrum, W., Brummelhuis, A., Collis, B., Plomp, T., \& Janssen, I. (1997): Technology Assessment of Multimedia Systems for Pre-primary and Primary Schools. Luxembourg: European Parliament, Scientific and Technological Options Assessment Panel 
Pelgrum, W. J., - Anderson, R. E., (eds.) (1999): ICT and Emerging Paradigm for Life-long Learning: a Worldwide Educational Assessment of Infrastructure, Goals and Practices. The Netherlands: International Association for the Evaluation of Educational Achievement

Pelgrum, W. J. - Plomp, T. (2002): Indicators of ICT in Mathematics: Status and Covariation with Achievement Measures. In: A. E. Beaton - D. F. R. Robitaille: Analyses of TIMMS-data. Dordrecht: Kluwer

Pelgrum, H. (2003): Promoting Equity Through ICT - What Can International Assessments Contribute to Help Fight Low Achievement? Előadás, Budapest, OECD Workshop, Promoting Equity Through ICT". Megjelenik a konferenciakötetben, szerk. Kárpáti Andrea.: Promoting Eqity Through ICT - Proceedings of the OECD Workshop, Budapest, 11-12 June 2003, Párizs: OECD

Perkins, D. (1992): Smart Schools: from Training Memories to Educating Minds. N.Y.: The Free Press.

Petraglia, J. (1998): Reality by Design: The Rhetoric and Technology of Authenticity in Education. Mahwah, N.J.: Lawrence Erlbaum Associates

Rogers, E. (1995): Diffusion of Innovations. N.Y.: Free Press

Rowan, B. - Miskel, C. (1999): Institution Theory and the Study of Educational Organizations. In: J. Murphy - K. A. Louis (eds.), Handbook of Research on Educational Administration (2nd ed., pp. 359-383). San Francisco: Jossey-Bass

Salomon, G. (2002): Technology and Pedagogy: Why don't We See the Promised Revolution? Educational Technology, 2002, Vol. XLII, Number 2 (March-April)

Sarason, B. S. (1990): The Predictable Gailure of Educational Reform. San Francisco: Jossey-Bass

Schank, R. - Yona, M. (1991): Empowering the Student: New Perspectives on the Design of Teaching Systems. Journal of the Learning Sciences, 1, 7-36.

Simon, H. A. (1982): The Sciences of the Artificial. Cambridge, MA: The MIT Press.

SNE (2003): Information and Communication Technology (ICT) in Special Needs

Education. (Az SNE projekt eredményeit közlő adatbázis:

http://www.european-agency.org/ict_sen_db/index.html)

G. J. W., Soriano, V., \& Watkins, A. (2003): Special Needs Education in Europe: Thematic Publication. Middelfart, Denmark

Vári Péter (2000): A MONITOR 1999 eredményei

Venezky, R. - Kárpáti, A.: ICT and the Quality of Learning. Special Issue of the International Journal of Education, Communication and Information. 2004/1 (in press)

Venezky, R., - Davis, C. (2002): Quo vademus? The Transformation of Schooling in a Networked World. Preliminary research report. Paris: OECD/CERI.

Wood, D. (2002): The THINK Report. Technology in Education: Futures for Policy. Bruxelles: European Schoolnet 